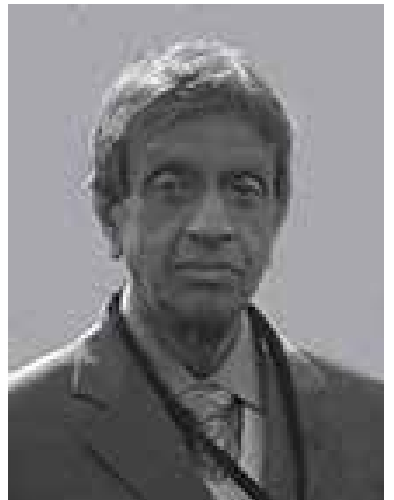

\section{Dr.DVJ Harischandra}

Senior Consultant Psychiatrist D. V. J. Harischandra passed away after a sudden illness on March 1, 2013, ten days shy of his seventy fifth birthday. A man who devoted all of his adult life towards the cause of promoting mental health in Sri Lanka, he died in harness as he was preparing to participate in a television talk show on related issues.

Dickwella Vidanage Jayaratne Harischandra was born on the 11th of March 1938 in the picturesque village of Mihiripenna near Talpe in Galle. He schooled at St. Aloysius College, Galle and obtained his MBBS degree from the University of Ceylon in 1964.

Opting for a career in Psychiatry, Dr. Harischandra underwent his postgraduate training in the United Kingdom where he trained at the famous Tavistock Clinic in London and the University of Edinburgh in Scotland.

Returning to Sri Lanka, Dr. Harischandra served as a consultant psychiatrist in several stations before returning to his native Galle. There he served the Teaching Hospital in Karapitiya as one of its consultants and joined the Department of Psychiatry of the Faculty of Medicine, University of Ruhuna.

Dr. Harischandra was head of that Department as well as Chairman of the Board of Study in Psychiatry at the Postgraduate Institute of Medicine, University of Colombo. He was also President of the Sri Lanka Psychiatric Association, the forerunner to the Sri Lanka College of Psychiatrists.

As a psychiatrist, Dr. Harischandra was courageous enough to pioneer the use of some types of therapies in Sri Lanka. His use of psychodrama and hypnosis attracted trainee psychiatrists from all parts of the country to his unit at the Karapitiya Teaching Hospital. Dr. Harischandra was a self-confessed Freudian. He admitted to being enamoured by Sigmund Freud's views at an early stage in his training and often used Freudian concepts to interpret and illustrate varied clinical presentations.

Dr. Harischandra was also a much sought after lecturer, trainer and examiner of postgraduate trainees in Psychiatry and several generations of psychiatrists serving in Sri Lanka and overseas would have fond memories of him as a teacher, mentor and role model.
Such laurels rested lightly on Dr. Harischandra. He was first and foremost an excellent communicator and it was this attribute that made him a household name in the country, especially with the advent of electronic media.

Dr. Harischandra reveled in this and made an enormous contribution towards changing public attitudes towards mental health by demystifying archaic concepts and reducing the stigma associated with mental disorders. In a nation where superstitions and supernatural beliefs are well entrenched, he did so with a variety of tools: an excellent command of the Sinhala and English languages, an extensive knowledge of Buddhist philosophy and the uncanny knack of being able to explain psychiatric and psychological phenomena in a cultural and religious milieu that was both understandable and acceptable to the masses. In a sense, he was the prefect scholar in a Sri Lankan context, blending the East and West and able to quote Freud or Fa Hien, Melanie Klein or Mahaushadha with equal ease.

He may have been a psychiatrist by profession but Dr. Harischandra was arguably the most versatile professional in the specialty in this country. There were many facets to his life for he was also a songwriter, author, film critic, Buddhist scholar, researcher on reincarnation phenomena and linguist. He played each of these roles with aplomb.

Some of Dr. Harischandra's achievements in the varied spheres are worthy of mention. He produced 'Jaathaka Geetha Sangrahaya', a compact disc of twenty songs written by him and set to the music of popular Hindi songs. He also wrote 'Psychiatric Aspects of Jataka Stories', a book that explored the psychiatric connotations hidden in Buddhist literature and won him a state literary award.

A regular contributor to the print media, Dr. Harischandra often critiqued movies highlighting the psychological aspects of their storylines. He was also an avid follower of the late Munidasa Cumaratunga and coined many words that today serve as technical terms in Psychiatry in Sinhalese.

Dr. Harischandra retired in 2003 but continued to practice in the private sector. If anything, retirement served to free up time constraints and he was soon a popular choice as a panelist on television. Always possessed of a keen sense of humour, he remarked at the farewell accorded to him at Teaching Hospital, Karapitiya on his retirement that he viewed it as "retyre-ment", an opportunity to equip himself for an even longer journey!

Indeed, Dr. Harischandra was not merely a doctor and academic, he was a fun loving personality as well. Psychiatrists will remember him as a great raconteur who did not shy away from the risqué joke or the razor sharp repartee that earned laughs all- round. And few were the gatherings of psychiatrists which wouldn't end with the melodious rendition of a Hindi song by him! 
There are also many stories-possibly embellished and exaggerated-about Dr. Harischandra's absent mindedness. The man who quoted Buddhist texts and Freud's teachings effortlessly was known to be absentminded in his day-to-day life but most importantly, he saw the funny side of this and was able to laugh at himself.

All those who knew him closely and worked with him marveled at Dr. Harischandra's versatility and erudition but what endeared him most was his humility and his concern for the welfare of those he associated with, be they patients, colleagues or students.

Despite his stature as a professional and a scholar of the highest repute, Dr. Harischandra was modest to a fault and often spoke on behalf of the underdog. He commanded immense respect but didn't abuse that respect to belittle others or to generate controversy. It is impossible to recall an occasion when he was angry. The faithful student of Freud that he was, he probably was too conscious of the perils of the ego.

A devoted family man, Dr. Harischandra was, despite keeping a hectic schedule until his very last day, a loving husband and father. He leaves behind his wife Padma and daughters Neshantha, Tolusha and Navoda.

May he attain Nibbana

\section{Rajiv Weerasundera}

